\title{
Behavior in Relation to Umbilical Infection in Vrindavani Calves
}

\author{
Brijesh Patel $^{1}{ }^{*}$, Mukesh Singh ${ }^{1}$, Pankaj Kumar Patel ${ }^{2}$, Pratik R. Wankhade ${ }^{1}$, \\ Vipin Morya $^{1}$, Deepanshu Gupta ${ }^{3}$, P.K. Bharti ${ }^{1}$ and S. Koochewad ${ }^{1}$ \\ ${ }^{1}$ Division of LPM, ${ }^{2}$ Division of Medicine, \\ ${ }^{3}$ Division of Animal Physiology, ICAR-Indian Veterinary Research Institute, Izatnagar, \\ Bareilly (U.P.), India \\ *Corresponding author
}

\begin{tabular}{|l|}
\hline K e y w o r d s \\
Behavoir, Short \\
lying, Ventral lying, \\
Vrindavani calves, \\
etc.
\end{tabular}

\section{Introduction}

Calves are the future replacement stocks. In
the calf rearing, the key management objective
is to ensure that calves survive and remain

Calves are the future replacement stocks. In
the calf rearing, the key management objective
is to ensure that calves survive and remain

Calves are the future replacement stocks. In
the calf rearing, the key management objective
is to ensure that calves survive and remain

\section{A B S T R A C T}

Present investigation was carried out to study the behaviour in relation to sickness in vrindavani calves. All Vrindavani calves (Age 0 to 3 month) born between January to August 2018 was selected. During this period approximate 80 calves were born. All calves were examined daily for clinical sign of umbilical infections. In our study we observed 10 calves affected with umbilical infection (navel-ill). The calves suffering from umbilical infection were considered as a diseased calf during study period. For each diseased calf, a healthy calf on the same date, of the same breed, and similar age was identified as the matched pair. After clinical examination all experimental calves were divided into 2 equal groups viz., healthy (Control) and Sick (Treatment). Behavioral observations were observed during day hours by CCTV camera. Calves with navel-ill more likely to be short lying than their healthy cohorts $(\mathrm{p}<0.05)$. Ventral lying and short lying were observed in $20 \%(2 / 10)$ and $40 \%$ (4/10) of navel-ill calves, respectively. Ventral lying was observed in $50 \%(5 / 10)$ of calves in the control group. There was no difference in the proportion of calves ventral lying in the navel-ill and control groups $(\mathrm{p}>0.05)$. Lateral lying and lying with neck extended was observed in $30 \%(3 / 10)$ calves and $10 \%(1 / 10)$ calf in the navelill group, respectively. For the human approach test, $60 \%(6 / 10)$ of calves never approached the observer, $10 \%$ (1/10) approached the observer during only one observation period, $10 \%$ (1/10) approached the observer at two of the observation periods, and $20 \%$ $(2 / 10)$ of calves approached the observer during all three observation periods. In vigilance test significant $(\mathrm{p}<0.05)$ difference were observed in face response. healthy (Jozica et al., 2012). Calf mortality accounts significantly to the total mortality in the dairy farm (Kumaresan et al., 2009). Calf mortality causes the loss of genetic material for herd improvement and decreases the 
number of dairy heifers available for herd replacement and expansion. Radostits et al., (2009) reported an estimated reduction of 38 $\%$ of net profit due to $20 \%$ calf mortalities. Economic losses resulting from calf mortality and morbidity can be easily recognized, but the effect of morbidity on future health and performance, which may constitute a loss of even greater importance, is difficult to estimate. It is generally attributed to many diseases viz. diarrhea, pneumonia, naval ill, Joint ill, parasitism etc. Across species there are sets of predictable physiologic and behavioral responses associated with pathogens, and parasitic infection. These responses include pyrexia, anorexia, depression, lethargy, and decreased grooming and are considered to have evolved because of the increased probability for survival of the host (Hart 1988). In cattle, these changes have been used to identify sick animals. There is interest in using these behaviors to identify and treat animals early in order to avoid the negative effects of disease on calves' performance and welfare (Millman, 2007; Weary et al., 2009).

Behavior is becoming an important tool to identify ill animals. Behaviors have been associated with ill health since the ancient Egyptians (Griffith, 1898) and Aristotle (Treatise: "On the Sacred Disease" 400 BC). More recently, research has determined that an animal's behavior can indicate pain and malaise associated with poor health, but can also predict those at risk (Weary et al., 2009). Producers and veterinarians have always used behavior for diagnosis of sickness in animals, although the observation of first signs usually signifies that the pathogen has already done considerable damage to the host. Lethargy, depression, anorexia and sleep disorders are among the most characteristic signs of the sickness behavior. Some authors have tried to establish whether changes in continuously monitored ethograms could be used as diagnostic tools (Eberhardt et al., 2003) but results have been limited. Animals respond to illness with a consistent pattern of behavioral changes, including reduced feeding and social behavior and increased rest (Johnson, 2002; Dantzer and Kelley, 2007). Keeping in view the problem of dairy calf diseases at the farm level and its detection through a change in specific calf behaviors using CCTV video recording system the present study was undertaken with the following objectives: To investigate the effect of illness on behavior changes of calves during navel infection.

\section{Materials and Methods}

\section{Location and Climatic conditions}

The farm is located at an altitude of $169.2 \mathrm{~m}$ above the mean sea level, at latitude of 28022' north and at the longitude of 79024' east. This place falls in upper Gangetic Plain Region of India. Generally, it has a humid subtropical climate with high variation between summer and winter temperatures. Summers are long, from early April to October, with the monsoon season in between. Winter starts in October and peaks in January. Extreme temperatures range from $4^{\circ} \mathrm{C}$ to $44^{\circ} \mathrm{C}$. The annual mean temperature is $25^{\circ} \mathrm{C}\left(77^{\circ} \mathrm{F}\right)$, monthly mean temperatures range from $14^{\circ} \mathrm{C}$ to $33^{\circ} \mathrm{C}\left(58{ }^{\circ} \mathrm{F}\right.$ to $\left.92{ }^{\circ} \mathrm{F}\right)$. The average annual rainfall is approximately $1714 \mathrm{~mm}$ (28.1 inches), most of which is during the monsoons in July and August.

\section{Experimental animals}

All Crossbred (Vrindavani) calves (Age 0 to 3 month) between January 2018 to August 2018 was selected. During this period approximate 80 calves were born. All calves were examined daily for clinical illness like diarrhea, pneumonia, umbilical infections and joint-ill. In the present study observed 10 calves affected with navel infection. The 
calves suffering from navel infection were considered as a diseased calf during study period. For each diseased calf, a healthy calf on the same day, of the same breed, and similar age was identified as the matched pair. After clinical examination all experimental calves were divided into 2 equal groups viz. Healthy (Control), and Sick (Treatment).

\section{Health and hygiene practices}

All the calves were reared under strict management and proper hygienic conditions throughout the period of the study. De worming and disbudding was done during second week of the calf's age.

Good sanitation of the pens, feeding utensils, water containers and surrounding experimental area was maintained during the period of experiment. The pens were cleaned daily and all hygienic precaution was taken to prevent the incidence of infectious and contagious diseases.

\section{Housing of calves}

The calves were housed individually in well ventilated, clean and dry cemented concrete pens for 18 hours (from $3.00 \mathrm{pm}$ to $9.00 \mathrm{am}$ ) throughout the experimental periods.

They were let loose for 6 hours (9.00am to $3.00 \mathrm{pm}$ ) daily in open paddock for exercise and also to facilitate washing, cleaning and drying of calf pens. Free access to fresh, clean and wholesome water along with green fodder was given to the calves.

\section{Feeding schedule of calves}

After colostrum feeding the calves were maintained on whole milk. Calf starter and roughage was provided adlib from second weeks onwards. The feeding schedule of the calves is presented in table 1 .

\section{Health Assessments and Disease Definitions}

Calves were examined for clinical signs of navel infections. A. The umbilicus of every calf was palpated which show pain and inflammation was considered as infected (McGuirk, 2008). Febrile calves were identified by a rectal temperature $\geq 39.4^{\circ} \mathrm{C}$. Healthy controls were defined as calves with fecal, joint, and navel scores of a 1 or 0 and rectal temperature $\leq 39.4^{\circ} \mathrm{C}$ (Table 2).

\section{Parameters recorded}

\section{Behavioral parameters}

Behavioral observations were observed during day hours. After recording video film was observe by single observer for categorizing various behavior activities in table 3 .

An initial response test, or "Vigilance Test", was created to determine each calf's initial response to the observer. Four types of responses were observed; face, profile, escape and ignore. It was assumed that facing the observer (face) or standing in profile to the observer (profile) were the normal responses to the presence of an observer. Escape was included as a measure of active withdrawal from the observer. The ignore response was expected to be the lowest vigilance response.

\section{Statistical analysis}

The information collected by data sheet would be pooled and analyzed as per standard statistical procedure (Snedecor and Cochran, 1989). Statistical analysis was done by appropriate method with SPSS version 22 software.

\section{Results and Discussion}

Calves with navel-ill more likely to be short lying than their healthy cohorts $(\mathrm{p}<0.05)$. 
Ventral lying and short lying were observed in $20 \%(2 / 10)$ and $40 \%$ (4/10) of navel-ill calves, respectively. Ventral lying was observed in $50 \%(5 / 10)$ of calves in the control group. There was no difference in the proportion of calves ventral lying in the navel-ill and control groups $(\mathrm{p}>0.05)$. Lateral lying and lying with neck extended was observed in $30 \%(3 / 10)$ calves and $10 \%(1 / 10)$ calf in the navel-ill group, respectively. One control calf was observed short lying and no control calves were observed lateral lying or lying with neck extended. For the human approach test, $60 \%$ $(6 / 10)$ of calves never approached the observer, $10 \%$ (1/10) approached the observer during only one observation period, $10 \%$ $(1 / 10)$ approached the observer at two of the observation periods, and $20 \%(2 / 10)$ of calves approached the observer during all three observation periods.

The most common response to the vigilance test was facing the observer regardless of navel-ill status are presented in table 4.

Table.1 Feeding schedule of the calves at calf section of IVRI

\begin{tabular}{|l|l|l|}
\hline Days & Colostrum & Whole milk \\
\hline $\mathbf{0 - 3}$ & $1 / 10^{\text {th }}$ Colostrum & $\overline{1}$ \\
\hline $\mathbf{4 - 5 6}$ & - & $1 / 10^{\text {th }}$ of BW \\
\hline $\mathbf{5 7 - 6 3}$ & - & $1 / 20^{\text {th }}$ of BW \\
\hline $\mathbf{6 4 - 7 2}$ & - & $1 / 40^{\text {th }}$ of BW \\
\hline
\end{tabular}

Table.2 Standardized health scoring system (McGuirk, 2008)

\begin{tabular}{|c|c|c|c|c|}
\hline Variable & Score 0 & Score 1 & Score 2 & Score 3 \\
\hline Umbilical score & $\begin{array}{l}\text { Cord cannot be } \\
\text { found; umbilical } \\
\text { opening is completely } \\
\text { flush with the } \\
\text { abdomen of the calf }\end{array}$ & $\begin{array}{l}\text { Cord can be palpated, } \\
\text { but is soft and } \\
\text { approximately the } \\
\text { size of a pencil }\end{array}$ & $\begin{array}{l}\text { Cord is larger } \\
\text { than a pencil, but } \\
\text { the calf does not } \\
\text { react when } \\
\text { palpated }\end{array}$ & $\begin{array}{l}\text { Umbilical is very } \\
\text { swollen, hard, and } \\
\text { hot to the touch, } \\
\text { and calf reacts } \\
\text { when palpated }\end{array}$ \\
\hline
\end{tabular}

Table.3 Description of different behavioral activities recorded is as follows by Stanton, A.

(2011)

\begin{tabular}{|l|l|}
\hline Lying Posture & $\begin{array}{l}\text { Calf was lying with legs tucked under body or one front leg extended in front of body and } \\
\text { head resting in relaxed and upright position }\end{array}$ \\
\hline Short Lying & Calf was lying with head tucked tight to side of body and limbs tucked under body \\
\hline Neck Extended & Calf was lying ventrally with neck and nose extended straight in front of body \\
\hline Lateral Lying & Calf was recumbent with all four legs extended to the side \\
\hline Vigilance Test & Calf orients towards observer \\
\hline Face & Calf stands with head and body parallel to observer \\
\hline Profile & Calf immediately moves away from observer \\
\hline Avoidance & Calf does not alter behavior in response to observer \\
\hline Ignore & \\
\hline Human Approach Test & Calf approached observer within 30 seconds of standing \\
\hline Approach & Calf did not approach observer within 30 seconds of standing \\
\hline No Approach & \\
\hline
\end{tabular}


Table.4 Proportional responses of navel-ill and control calves to the observer during Vigilance testing

\begin{tabular}{|l|l|l|}
\hline Response & Control Calves & Navel -ill Calves \\
\hline Face & $70 \%(7 / 10)^{\mathrm{a}}$ & $50(5 / 10)^{\mathrm{b}}$ \\
\hline Profile & $10 \%(1 / 10)$ & $20(2 / 10)$ \\
\hline Escape & $10 \%(1 / 10)$ & $10(1 / 10)$ \\
\hline Ignore & $10 \%(1 / 10)$ & $20(2 / 10)$ \\
\hline
\end{tabular}

Means bearing different superscripts in a row differ significantly $(\mathrm{p}<0.05)$.

Lying behavior was assessed based on the hypothesis that animals alter their behavior during illness. The use of different lying postures have recently been used in the identification of pain associated with illness (Todd 2007) and have previously been validated for use in lambs following castration (Molony et al., 2002).

The use of vigilance tests and human approach tests are novel tests in the field of sickness behavior. Lying posture was divided into four categories based on the hypothesis that animals during the clinical phase of disease will alter their behavior to conserve their energy or minimize the discomfort associated with clinical signs.

It was hypothesized that short lying would be adopted to conserve energy by reducing the surface area exposed to the environment and reducing the lower critical temperature (Schrama et al., 1993). Calves may also be altering their lying behavior during the first observation period in response to discomfort from navel ill, since ventral lying was more common in the navel ill. Calves resting with an extended neck were observed very rarely in the sub-sample of clinically diseased calves and their healthy cohorts. Lateral lying was also observed very rarely, and as such no conclusions can be drawn with respect to the usefulness of this behavioral response as a tool for identifying sick animals. However, it is worth noting that no control calves in the navel ill analysis were observed lateral lying.
The proportion of calves willing to approach the observer was $80 \%$ in the healthy cohort and $40 \%$ in the navel ill. Calves with navel ill may be in discomfort from pain and inflammation of the navel flap, which may cause the greatest reluctance to approach. Alternatively, calves with navel ill may be anorexic and lethargic which would decrease their motivation to approach towards observer.

In conclusion, short lying appears to be a highly specific indicator of navel ill since it was more likely to be performed during navel ill. However, short lying was uncommon. For this reason, behavioral measures such as willingness to approach the observer may be useful to identify animals with umbilical infection. These behaviors could be integrated into future studies of predictors of disease and discomfort as well as used on farm for training of personnel in disease detection.

\section{References}

Dantzer, R. and Kelley, K. W. 2007. Twenty years of research on cytokine-induced sickness behavior. Brain Behav. Immun. 21:153-160

Eberhardt, T., Grimm, H., Richter, T. and Savary, P. 2003. Early detection of calf diseases by automatic recording of behavioural changes. In: K. Janni (Ed.) Proc. 5th Int. Dairy Housing Conf., Fort Worth, TX. Am. Soc. Agric. Eng., St. Joseph, MI. pp. 350-355 
Griffith, F. L. I. 1898. The Petrie PapyriHieratic Papyri from Kahun and Gurob. Bernard Quartich, London, UK

Johnson, R.W. 2002. The concept of sickness behavior: a brief chronological account of four key discoveries. Vet. Immunol. Immunopath. 87: 443-450

Jozica, J., Tadej, M. and Martina, K. 2012. Serum immunoglobulin (IgG, IgM, IgA) concentration in cows and their calves. 20th Int. Symp. "Animal Science Days", Kranjska gora, Slovenia, Sept. 19th-21th, ACTA AGRIC. SLOV.3:295-298

Kumaresan, A., Behera, K., Mohanty, T.K., Shiv Prasad and Layek, S.S. 2009. Strategizing managemental practices for dairy calves. Intas Polivet, 10(II):129138

Millman, S. T. 2007. Sickness behaviour and its relevance to animal welfare assessment at the group level. Anim. Welfare, 16: 123-125

Molony, V., Kent, J. E. and McKendrick, I. J. 2002. Validation of a method for assessment of an acute pain in lambs. Appl. Anim. Behav. Sci. 76: 215-238

Radostits, O.M., Gay, C.C., Blood, D.C. and
Hinchcliff 2009. Veterinary Medicine. A text book of diseases of cattle, sheep. Pigs, goats and horses. 10th edn., New York, W.B. Saunders Company Ltd. pp. 779-781

Schrama, J. W., Arieli, A., Brandsma, H. A., Luiting, P. and Verstegen, M. W. 1993. Thermal requirements of young calves during standing and lying. J. Anim. Sci. 71: 3285-3292.

Snedecor, G.W. and Cochran, W.G. 1989. Statistical methods. 6th Ed., The lowa State University Press, Ames, Lowa, USA

Stanton, A. 2011. An evaluation of the impact of management practice in the health and welfare of dairy heifer calves (Doctoral thesis, University of Guelph, Ontario, Canada)

Todd, C. G. 2007. Effects of meloxicam (metacam) therapy on the behaviour of dairy calves with neonatal calf diarrhea complex. MSc Thesis, University of Guelph.

Weary, D. M., Niel, L., Flower, F. C. and Fraser, D. 2009. Identifying and preventing pain in animals. Appl. Anim. Behav. Sci. 100:64-76

\section{How to cite this article:}

Brijesh Patel, Mukesh Singh, Pankaj Kumar Patel, Pratik R. Wankhade, Vipin Morya, Deepanshu Gupta, P.K. Bharti and Koochewad, S. 2019. Behavior in Relation to Umbilical Infection in Vrindavani Calves. Int.J.Curr.Microbiol.App.Sci. 8(07): 1859-1864. doi: https://doi.org/10.20546/ijcmas.2019.807.221 